\title{
Analysis of Support Vector Machine (SVM) Method and Simple Additive Weighting (SAW) Method in Making Decisions to Choose Specialization
}

\author{
Stevanny Tamaela ${ }^{1}$, Yopi Andry Lesnussa ${ }^{2}$, V. Y. I. Ilwaru ${ }^{3}$, A. M. Balami ${ }^{4}$ \\ ${ }^{1}$ Universitas Pattimura Ambon, annytamaela@gmail.com \\ ${ }^{2}$ Universitas Pattimura Ambon,yopi_a_lesnussa@yahoo.com \\ ${ }^{3}$ Universitas Pattimura Ambon, vennilwaru007@gmail.com \\ ${ }^{4}$ Universitas Pattimura Ambon, abdulmalikbalami@gmail.com
}

doi: https://doi.org/10.15642/mantik.2020.6.2.104-113

\begin{abstract}
Abstrak. Peminatan peserta didik adalah suatu pembelajaran berbasis minat peserta didik sesuai kesempatan belajar yang ada dalam satuan pendidikan. Penyelenggaraan pendidikan dalam satuan pendidikan di SMA berdasarkan kurikulum 2013 terdapat program penentuan peminatan bagi peserta didik SMA yang dilaksanakan di kelas X. Peminatan dalam kurikulum 2013 di SMA adalah kelompok peminatan IPA dan IPS. Penelitian ini menggunakan metode Support Vector Machine (SVM) dan metode Simple Additive Weighting (SAW) yang bertujuan untuk membandingkan tingkat keakuratan tiap metode dalam Sistem Pengambilan Keputusan (SPK) peminatan IPA dan IPS pada SMA Negeri 1 Ambon. Dari hasil penelitian diperoleh hasil pemilihan peminatan dari metode SAW berbeda dengan data riil, sedangkan hasil dari metode SVM menunjukan hasil yang sama dengan pemilihan peminatan riil di SMA Negeri 1 Ambon.
\end{abstract}

Kata kunci: Kurikulum 2013; Support vector machine; Simple additive weighting

\begin{abstract}
The specialization of students is a learning based on the interests of students according to learning opportunities that exist in educational units. Providing education in high school education units based on the 2013 curriculum there is a program for determining specialization for high school students held in class X. Specialization in the 2013 curriculum in high schools is the specialization group for Natural Sciences and Social Sciences. This study uses the Support Vector Machine (SVM) method and the Simple Additive Weighting (SAW) method which aims to compare the accuracy of each method in Decision Making (SPK) specialization program in the Natural Science and Social Sciences at SMA Negeri 1 Ambon. From the research results, the results of the specialization selection from the SAW method differ from the real data, while the results of the SVM method show the same results as the selection of real specialization in SMA Negeri 1 Ambon
\end{abstract}

Keywords: 2013 Curriculum; Support vector machine; Simple additive weighting

How to cite: S. Tamaela, Y. A. Lesnussa, V. Y. I. Ilwaru, and A. M. Balami, "Analysis of Support Vector Machine (SVM) Method and Simple Additive Weighting (SAW) Method in Making Decisions to Choose Specialization”, J. Mat. Mantik, vol. 6, no. 2, pp.104-112, October 2020. 


\section{Introduction}

The curriculum is the most important part of the National education system, whose existence has existed since the beginning of the existence of National education [1]. The curriculum is a plan about the formation of abilities and character of children based on a standard [2], 2013 curriculum is a curriculum that simplifies[3] and thematic-integrative, adding rainy hours to encourage students . One of the forms is class division specialization at the Senior High School level [4]. Specialization aims to provide opportunities for students to develop their interests in a group of subjects by their scientific interests in higher education[5] and develop their interest in a particular discipline or skill[6]. According to [6] Decision-Making System is the process of choosing between two or more alternative actions to achieve goals or objectives. Several studies have concluded that various decisionmaking methods can determine reliable results.

However, in this case, two methods will be applied including (1) the Support Vector Machine (SVM) Algorithm, the SVM method is a technique for making predictions, both in the case of classification and regression [7]. SVM was introduced by Boser, Guyon, Vanpik, and was first presented in 1992 [7] at the Annual Workshop on Computational Learning Theory. The basic concept of SVM is a harmony of computational theories that existed decades before, such as the hyperplane margin introduced by Aronszajn in 1950 However, up until 1992 there had never been any attempt to assemble these components. The basic principle of SVM is a linear classifier [8] and subsequently developed to work on non-linear problems by incorporating the concept of kernel tricks in high-dimensional space [9]. The main purpose of SVM is to increase speed in training and testing so that SVM can be used for large data (2) Simple Additive Weighing (SAW) method, the basic concept of the SAW method is to find the weighted sum of the performance ratings for each alternative on all attributes [10][11]. SAW can carry out a more precise assessment because it is based on criteria values [12] and weights that have been determined and can select the best alternative. Larger values indicate that alternatives are preferred [13]. The Simple Additive Weighting (SAW) method is recommended to solve the selection problem in a multi-process decision-making system [14]. Simple Additive Weight (SAW) method is a method that is widely used in decision making that has many attributes [15].

In this paper, we will compare the accuracy of SVM methods and SAW methods in decision making system to determine the specialization in SMA Negeri 1 Ambon.

\section{Methods}

The type of research used is a case study, by comparing the SVM method with the SAW method to determine the choice of interest in tenth grade students. The material used in this study is secondary data obtained from SMA Negeri 1 Ambon. Secondary data taken from SMA Negeri 1 Ambon in the form of a value criterion as a measure of interest selection include the initial test scores in SMA 1 or a comparative value to determine a Major Course in tenth grade students.

The Simple Additive Weighting (SAW) work process flowchart can be seen in the following figure: 


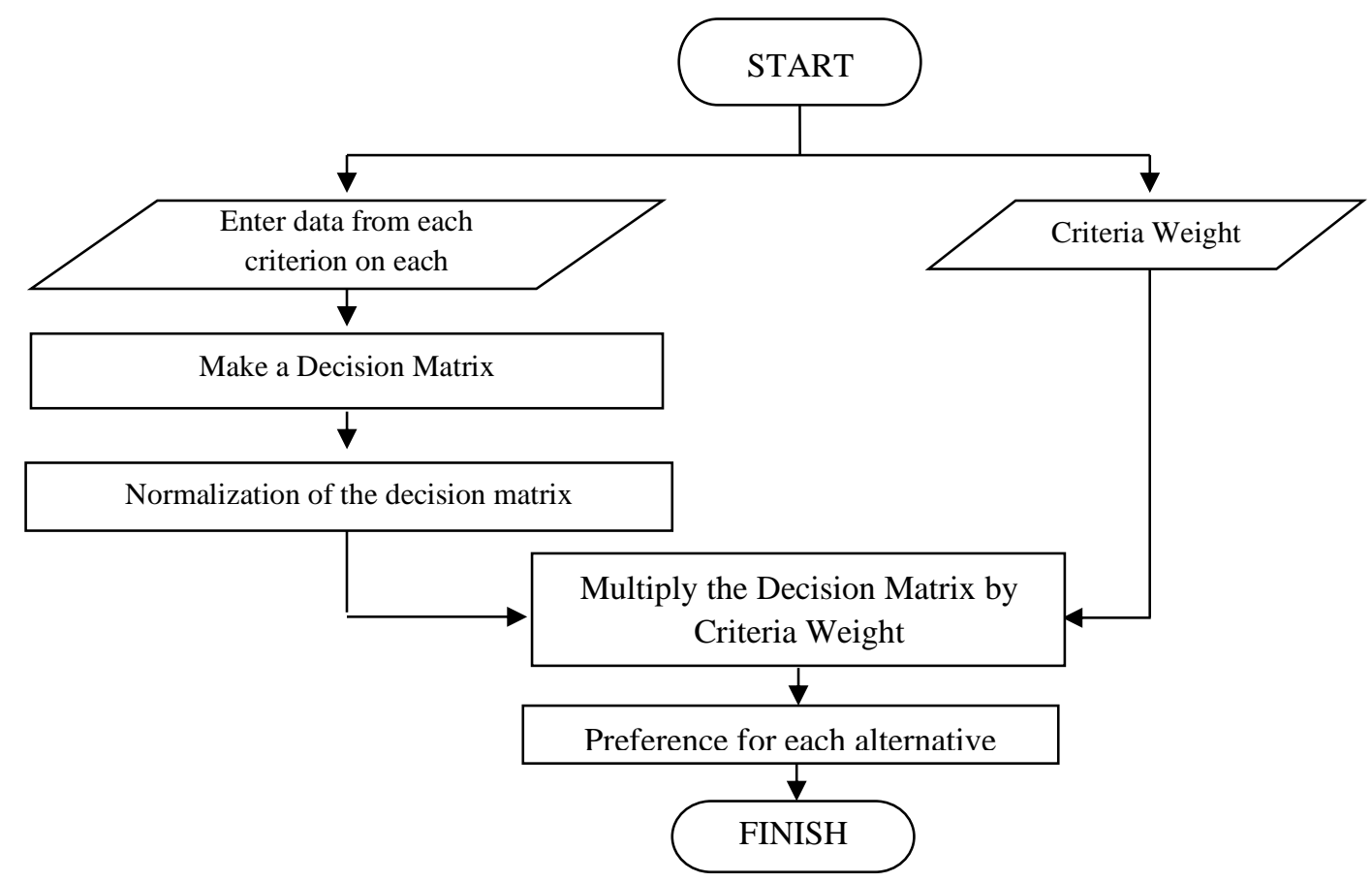

Figure 1. Simple Additive Weighting (SAW) work process flow chart

In detail the workflow diagram of the Support Vector Machine (SVM) can be seen in the following figure:

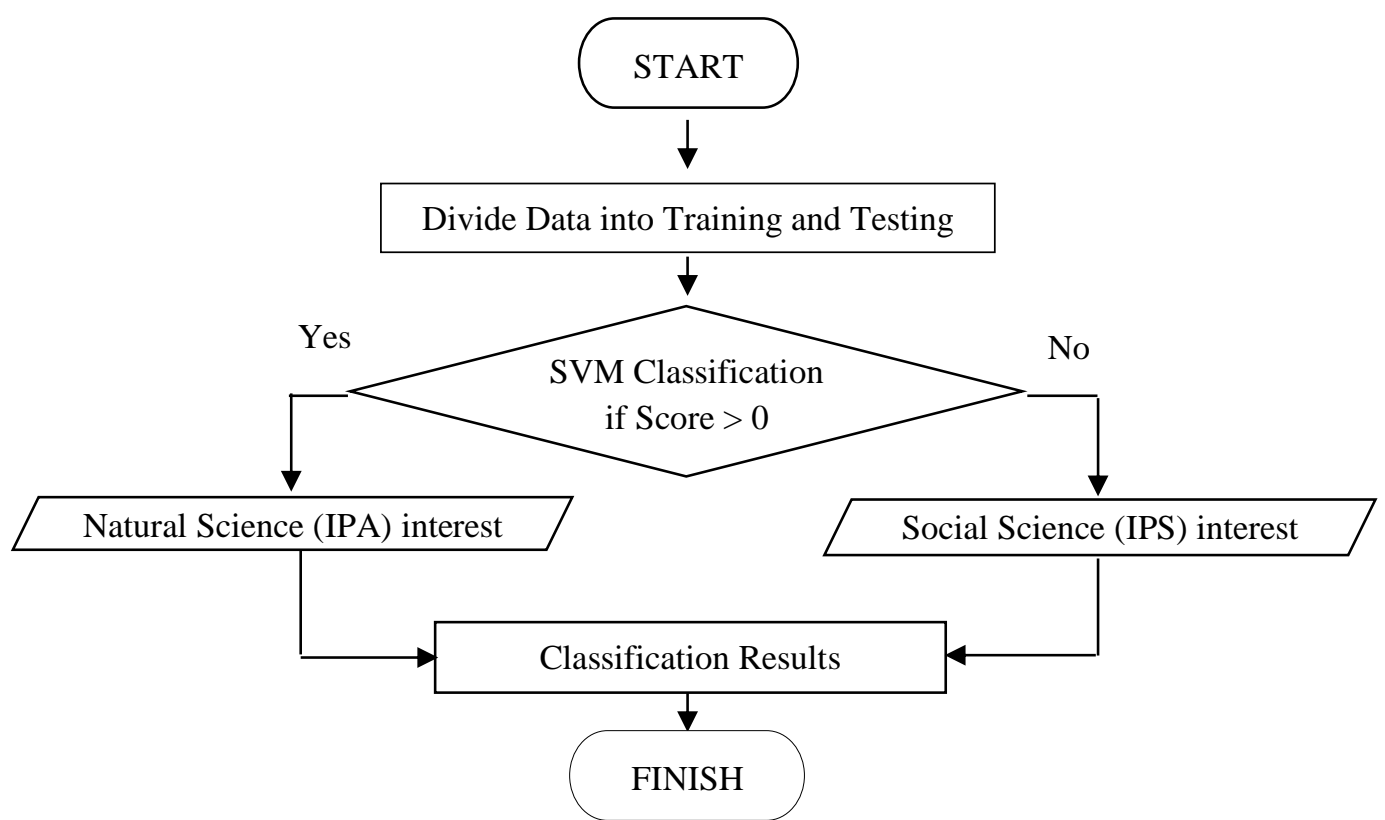

Figure 2. The work process of Support Vector Machine (SVM)

SVM linear search for hyperplane with the largest margin, known as the Maximum Marginal Hyperplane (MMH). Based on the Lagrangian formulation mentioned, MMH can be rewritten as a boundary decision:

$$
d\left(X^{T}\right)=\sum_{i=1}^{l} y_{i} \alpha_{i} X_{i} X^{T}+b_{0}
$$


where $y_{i}$ is the label vector support class $X_{i} . X^{T}$ is a test tuple; $\alpha_{i}$ and $b_{0}$ are numerical parameters that are automatically determined by the SVM algorithm, and 1 is the number of Support Vector.

\section{Results and Discussion}

\subsection{SAW Method}

For this research method, the variables used for data are the National Examination Score (C1), Entrance Test Score (C2), Psychological Value (C3). The amount of data in this study amounted to 50 data. The interest or major divide in 2 part, such as: Natural sciences department (IPA) and Social sciences department (IPS).

Table 1. Research Data

\begin{tabular}{cccccc}
\hline No & $\begin{array}{c}\text { Ne score } \\
(\mathbf{r e k})\end{array}$ & Initial Score Value & $\begin{array}{c}\text { Psychology } \\
\text { Score }\end{array}$ & $\begin{array}{c}\text { Final } \\
\text { Score }\end{array}$ & $\begin{array}{c}\text { Major/ } \\
\text { interest }\end{array}$ \\
\hline 1 & 82 & 35 & 106.7 & 74.57 & IPA \\
2 & 80.2 & 34 & 86.2 & 66.8 & IPS \\
3 & 80 & 34 & 100 & 71.33 & IPA \\
4 & 81.5 & 34 & 94.4 & 69.97 & IPS \\
5 & 80 & 34 & 93.9 & 69.30 & IPS \\
6 & 85.5 & 33 & 111.8 & 76.77 & IPA \\
7 & 84.5 & 33 & 111.9 & 76.47 & IPA \\
8 & 80 & 33 & 86.1 & 66.37 & IPS \\
9 & 81.5 & 33 & 109.6 & 74.70 & IPA \\
10 & 80.8 & 32 & 106.3 & 73.03 & IPA \\
11 & 80 & 32 & 97 & 69.67 & IPS \\
12 & 83 & 32 & 106.7 & 73.90 & IPA \\
13 & 82.5 & 32 & 92.6 & 69.03 & IPS \\
14 & 81.9 & 31 & 107.7 & 73.53 & IPA \\
15 & 80.5 & 31 & 92.6 & 68.03 & IPS \\
16 & 80 & 31 & 98.7 & 69.90 & IPS \\
17 & 81.5 & 31 & 83.3 & 65.27 & IPS \\
18 & 80 & 31 & 91.3 & 67.43 & IPS \\
19 & 85.5 & 30 & 90.6 & 68.70 & IPS \\
20 & 84.5 & 30 & 101.3 & 71.93 & IPA \\
21 & 80 & 30 & 89.7 & 66.57 & IPS \\
22 & 80 & 30 & 93.6 & 67.87 & IPS \\
23 & 83 & 30 & 88.3 & 67.10 & IPS \\
24 & 82.5 & 30 & 111.4 & 74.63 & IPA \\
25 & 81.9 & 30 & 97.7 & 69.87 & IPS \\
26 & 80.5 & 30 & 109.6 & 73.37 & IPA \\
27 & 80 & 30 & 104.5 & 71.50 & IPA \\
28 & 81.5 & 30 & 100 & 70.50 & IPA \\
29 & 83 & 30 & 91.1 & 68.03 & IPS \\
30 & 82.5 & 30 & 103.9 & 72.13 & IPA \\
31 & 81.9 & 30 & 100 & 70.63 & IPA \\
32 & 80.5 & 28 & 70.90 & IPA \\
33 & 83.9 & 28 & 72.63 & IPA \\
\hline & & & &
\end{tabular}




\begin{tabular}{cccccc}
\hline No & $\begin{array}{c}\text { Ne score } \\
(\mathbf{r e k})\end{array}$ & Initial Score Value & $\begin{array}{c}\text { Psychology } \\
\text { Score }\end{array}$ & $\begin{array}{c}\text { Final } \\
\text { Score }\end{array}$ & $\begin{array}{c}\text { Major/ } \\
\text { interest }\end{array}$ \\
\hline 34 & 84 & 28 & 92.9 & 68.30 & IPS \\
35 & 80.5 & 28 & 87.7 & 65.40 & IPS \\
36 & 80.4 & 28 & 86.9 & 65.10 & IPS \\
37 & 81.3 & 28 & 111.9 & 73.73 & IPA \\
38 & 81.9 & 28 & 92.5 & 67.47 & IPS \\
39 & 81 & 28 & 86.8 & 65.27 & IPS \\
40 & 80.2 & 28 & 105 & 71.07 & IPA \\
41 & 82 & 27 & 109.9 & 72.97 & IPA \\
42 & 83.6 & 27 & 110.5 & 73.70 & IPA \\
43 & 80 & 27 & 93.8 & 66.93 & IPS \\
44 & 82.5 & 27 & 94.9 & 68.13 & IPS \\
45 & 81.6 & 27 & 91.3 & 66.63 & IPS \\
46 & 85 & 27 & 106.6 & 72.87 & IPA \\
47 & 82.9 & 27 & 106 & 71.97 & IPA \\
48 & 83.5 & 27 & 94.7 & 68.40 & IPS \\
49 & 80 & 27 & 93.3 & 66.77 & IPS \\
50 & 80 & 27 & 111.1 & 72.70 & IPA \\
\hline
\end{tabular}

In this research process, the calculation process will be carried out using sample data from students who will register at SMAN 1 Ambon, using the SAW method. Alternative data used in the study are in table 2 .

Table 2. Alternative Data

\begin{tabular}{cc}
\hline Alternatives & $A i$ \\
\hline$A 1$ & Natural sciences (IPA) \\
$A 2$ & Social Sciences (IPS) \\
\hline
\end{tabular}

The criteria used to determine each alternative above are the National Examination Score, Initial Test Score, and Psychological Test Score. Departmental target data is divided into 3 groups with the following conditions:

Department of Natural Sciences for a value of $\leq 85$ with very clever provisions Department of Neutral for a Value of $70 \leq \mathrm{y} \leq 80$ with the provisions of the Average Ministry of Social Sciences for Low value of 70 with a low provision Note: $\mathrm{y}=$ Major

Based on subject criteria, it is determined that preference $(\mathrm{W})$ is $=\{30,30,40\}$. After preference weights are determined, a matrix is made based on the previous weighting table. Then, the X matrix is normalized, based on the equation of the SAW method to obtain an $\mathrm{R}$ normalized matrix, then the normalized matrix $\mathrm{R}$ is multiplied by $\mathrm{W}$ which is the weight of the predetermined preference. 
S. Tamaela, Y. A. Lesnussa, V. Y. I. Ilwaru, A. M. Balami, Analysis of Support Vector Machine (SVM) Method and Simple Additive Weighting (SAW) Method in Making Decisions to Choose Specialization

Table 3. $\mathrm{C}++$ Software Results Table

\begin{tabular}{|c|c|c|c|c|c|}
\hline No & $R_{i j} U N$ & $R_{i j} T A$ & $R_{i j} S P$ & $V_{i j}$ & Recommendation \\
\hline 1 & 0.75 & 1.00 & 0.67 & 79.17 & IPA \\
\hline 2 & 0.75 & 1.00 & 0.33 & 65.83 & IPS \\
\hline 3 & 0.75 & 1.00 & 0.33 & 65.83 & IPA* \\
\hline 4 & 0.75 & 1.00 & 0.33 & 65.83 & IPS \\
\hline 5 & 0.75 & 1.00 & 0.33 & 65.83 & IPS \\
\hline 6 & 1.00 & 1.00 & 1.00 & 100.00 & IPA \\
\hline 7 & 1.00 & 1.00 & 1.00 & 100.00 & IPA \\
\hline 8 & 0.75 & 1.00 & 0.33 & 65.83 & IPS \\
\hline 9 & 0.75 & 1.00 & 0.67 & 79.17 & IPA \\
\hline 10 & 0.75 & 1.00 & 0.67 & 79.17 & IPA \\
\hline 11 & 0.75 & 1.00 & 0.33 & 65.83 & IPS \\
\hline 12 & 0.75 & 1.00 & 0.67 & 79.17 & IPA \\
\hline 13 & 0.75 & 1.00 & 0.33 & 65.83 & IPS \\
\hline 14 & 0.75 & 1.00 & 0.67 & 79.17 & IPA \\
\hline 15 & 0.75 & 1.00 & 0.33 & 65.83 & IPS \\
\hline 16 & 0.75 & 1.00 & 0.33 & 65.83 & IPS \\
\hline 17 & 0.75 & 1.00 & 0.33 & 65.83 & IPS \\
\hline 18 & 0.75 & 1.00 & 0.33 & 65.83 & IPS \\
\hline 19 & 1.00 & 0.50 & 0.33 & 58.33 & IPS \\
\hline 20 & 1.00 & 0.50 & 0.33 & 58.33 & IPA* \\
\hline 21 & 0,75 & 0.50 & 0.33 & 58.33 & IPS \\
\hline 22 & 0.75 & 0.50 & 0.33 & 58.33 & IPS \\
\hline 23 & 0.75 & 0.50 & 0.33 & 58.33 & IPS \\
\hline 24 & 0.75 & 0.50 & 1.00 & 77.50 & IPA \\
\hline 25 & 0.75 & 0.50 & 0.33 & 50.83 & IPS \\
\hline 26 & 0.75 & 0.50 & 0.67 & 64.17 & IPA \\
\hline 27 & 0.75 & 0.50 & 0.33 & 50.83 & IPA \\
\hline 28 & 0.75 & 0.50 & 0.33 & 50.83 & IPA* \\
\hline 29 & 0.75 & 0.50 & 0.33 & 50.83 & IPS \\
\hline 30 & 0.75 & 0.50 & 0.33 & 50.83 & IPA* \\
\hline 31 & 0.75 & 0.50 & 0.33 & 50.83 & IPA* \\
\hline 32 & 0.75 & 0.50 & 0.33 & 50.83 & IPA* \\
\hline 33 & 0.75 & 0.50 & 0.67 & 64.17 & IPA* \\
\hline 34 & 0.75 & 0.50 & 0.33 & 50.83 & IPS \\
\hline 35 & 0.75 & 0.50 & 0.33 & 50.83 & IPS \\
\hline 36 & 0.75 & 0.50 & 0.33 & 50.83 & IPS \\
\hline 37 & 0.75 & 0.50 & 1.00 & 77.50 & IPA \\
\hline 38 & 0.75 & 0.50 & 0.33 & 50.83 & IPS \\
\hline 39 & 0.75 & 0.50 & 0.33 & 50.83 & IPS \\
\hline 40 & 0.75 & 0.50 & 0.33 & 50.83 & IPA \\
\hline 41 & 0.75 & 0.50 & 0.67 & 64.17 & IPA* \\
\hline 42 & 0.75 & 0.50 & 1.00 & 77.50 & IPA \\
\hline
\end{tabular}




\begin{tabular}{cccccc}
\hline No & $\boldsymbol{R}_{i j} \boldsymbol{U N}$ & $\boldsymbol{R}_{i j} \boldsymbol{T A}$ & $\boldsymbol{R}_{i j} \boldsymbol{S P}$ & $\boldsymbol{V}_{\boldsymbol{i j}}$ & Recommendation \\
\hline 43 & 0.75 & 0.50 & 0.33 & 50.83 & IPS \\
44 & 0.75 & 0.50 & 0.33 & 50.83 & IPS \\
45 & 0.75 & 0.50 & 0.33 & 50.83 & IPS \\
46 & 1.00 & 0.50 & 0.67 & 71.67 & IPA \\
47 & 0.75 & 0.50 & 0.67 & 64.17 & IPA* \\
48 & 0.75 & 0.50 & 0.33 & 50.83 & IPS \\
49 & 0.75 & 0.50 & 0.33 & 50.83 & IPS \\
50 & 0.75 & 0.50 & 1.00 & 77.50 & IPA \\
\hline
\end{tabular}

According to Table $3, R_{i j} \mathrm{UN}, R_{i j} \mathrm{TA}, R_{i j} \mathrm{SP}$, and $V_{i j}$ representing respectively, the weight of National Examination, Entrance Test, Psychological Value and the final score. From the final score or final value will use to determine the decision making to choose the specialization in natural sciences department or social sciences department.

\subsection{SVM Method}

For this research method, the variables used for data are the National Examination Score (X1), Entrance Test Score (X2), Psychological Value (X3). While the target or output is Class or Major Course (Y). The data used are the same as Table 1. This study uses the linear SVM method with MATLAB software to conduct data analysis. A comparison of training and testing data used is 70:30 from each grouping that has been determined.

The results of the software for grouping the training data are as follows:

Table 4. Software Results for Testing Data

\begin{tabular}{cccccc}
\hline No & $\begin{array}{c}\text { Original } \\
\text { Data }\end{array}$ & svmStruct1 & svmStruct2 & svmStruct3 & $\begin{array}{c}\text { Software } \\
\text { Results }\end{array}$ \\
\hline 1 & 0 & 0 & 0 & 0 & 0 \\
2 & 0 & 1 & 0 & 0 & 0 \\
\cline { 2 - 6 } 3 & 0 & 1 & 0 & 0 & 0 \\
4 & 0 & 0 & 0 & 0 & 0 \\
5 & 0 & 0 & 0 & 0 & 0 \\
6 & 0 & 0 & 0 & 0 & 0 \\
7 & 0 & 0 & 0 & 0 & 0 \\
8 & 0 & 1 & 0 & 0 & 0 \\
9 & 1 & 1 & 1 & 1 & 1 \\
10 & 1 & 1 & 1 & 1 & 1 \\
11 & 1 & 1 & 1 & 1 & 1 \\
12 & 1 & 1 & 1 & 1 & 1 \\
13 & 1 & 0 & 1 & 1 & 1 \\
14 & 1 & 1 & 1 & 1 & 1 \\
15 & 1 & 0 & 1 & 1 & 1 \\
16 & 1 & 1 & 1 & 1 & \\
\hline
\end{tabular}

From Table 4, it can be seen the SVM method classification shows the output with $100 \%$ accuracy for training data. And also, class 0 is a group of Natural Sciences Department) and class 1 is a group of Social Sciences Department. This can be seen from the comparison between the target data and the output target. svmStruct1, svmStruct1, 
svmStruct1 each representing national examination, entrance test, and psychological value. With Hyperplan obtained from each class as follows:

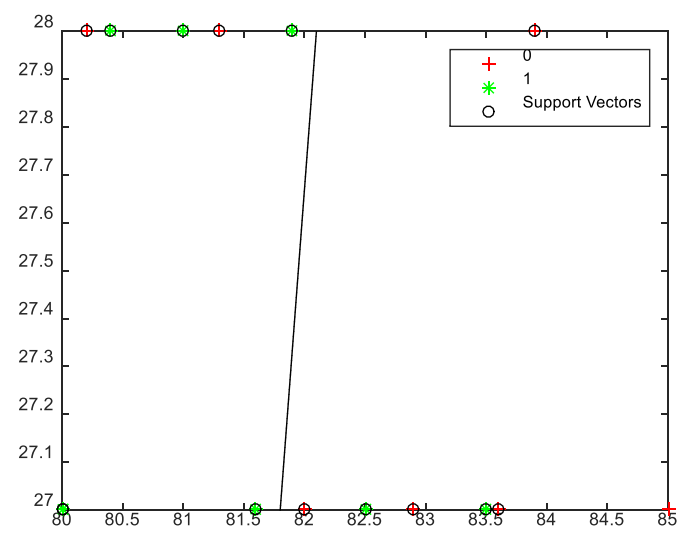

Figure 3. Hyperplane for svmStruct1

Based on Figure 3, it can be explained that the svmStruct1 data shows that the data in the two classes are not completely separate can be seen from several red circles whose distribution is around the green circle area.

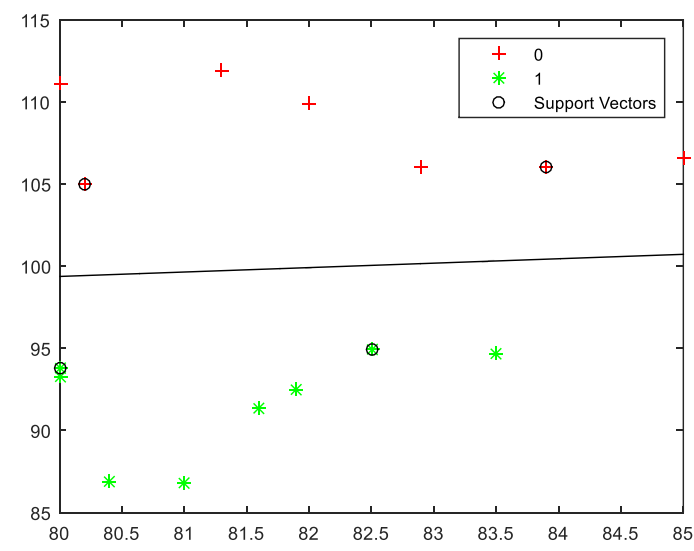

Figure 4. Hyperplane for svmStruct2

Based on Figure 4, it can be explained that the data in svmStruct1 is correctly classified in class 0 (a group of Natural Sciences Department) or class 1 (a group of Social Sciences Department) while the Support Vector is a circle within the circle.

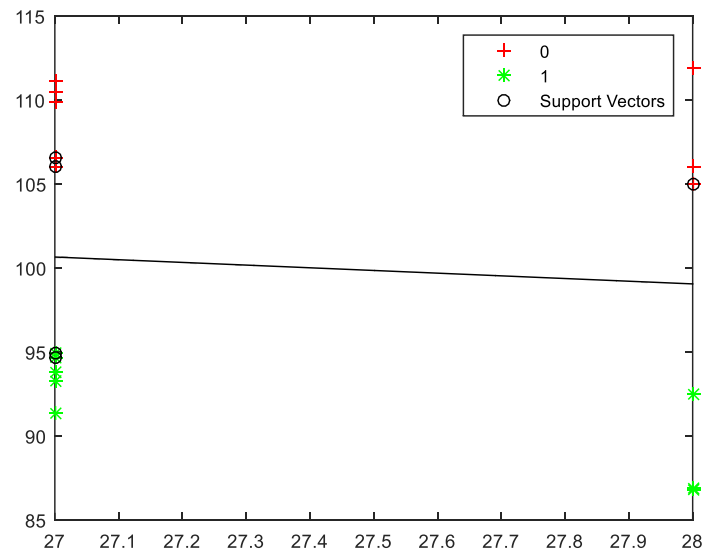

Figure 5. Hyperplane for svmStruct3 
Based on Figure 5, it can be explained that all svmStruct 3 data is properly classified into class 0 (which is the Natural Science Department) or class 1 (which is the Social Sciences Department), while the Support Vector is the circle within the circle.

By the purpose of this study to see the level of accuracy between the SAW method and the SVM method, so the results obtained namely the SAW method are found. From the results in Table 3 above it can be seen that 12 students can enter the natural science (IPA) class and 38 in the social science (IPS) class. This shows that there are differences in decision criteria in the Determination a Major Course according to the results of calculations with the SAW method in Table 3, with the results of student selection in the data in Table 1. Some of the different data can be seen in data 3, 20, 28, 30, 31, 32, 33, 41, 47 which are different from the actual data in Table 1. From these different data, the results of the SAW calculation are more suitable for the IPS interest class, but in the real data, it is in the IPA interest class. As for the SVM method, the results of the software output matched with the real data are seen that $100 \%$ of the output data is the same as the real data. This shows for the SVM method of Determining a Major Course carried out by the school according to the ability of children.

\section{Conclusions}

From the results and discussion can be conclude that, the results of research by the SAW method there are some students who have low criteria but are in the interest or department of Natural Sciences and vice versa. However, based on the results of research with the SVM method there are classifications of interest or majors that are different from the interests or classifications obtained are imperfect classifications.

\section{References}

[1] M. Ali, "Implementasi Kurikulum Pendidikan Nasional 2013," J. Pedagog., Vol. 2(2), pp. 49-60, 2013.

[2] M. Lestari, "Implementation of Citizenship Character Formation by the Study of Civic Education on Senior High School in The District of Bantul," E-CIVICS, Vol. 5 (6), 2016.

[3] Suyatmini, "Implementasi Kurikulum 2013 pada Pelaksanaan Pembelajaran Akuntansi di Sekolah Menengah Kejuruan," J. Pendidik. Ilmu Sos., Vol. 20(1), pp.60$68,2017$.

[4] Subandi, "Pengembangan Kurikulum 2013," J. Pendidik. dan Pembelajaran Dasar, Vol. 1(1), pp. 18-36, 2014.

[5] B. L. Julien, L. Lexis, J. Schuijers, T. Samiric, and S. McDonald, "Using capstones to develop research skills and graduate capabilities: A case study from physiology," J. Univ. Teach. Learn. Pract., Vol. 9(3), 2012.

[6] Direktorat Pembinaan SMA, Modul Pelatihan Implementasi Kurikulum 2013 SMA Tahun 2018. pp. 1-62, 2018.

[7] Y. Lin, H. Tseng, and C. Fuh, "Using Support Vector Machine," Image Process., pp.123-130, 2003.

[8] M. A. Oskoei and H. Hu, "Support vector machine-based classification scheme for myoelectric control applied to upper limb," IEEE Trans. Biomed. Eng., Vol. 55(8), pp. 1956-1965, 2008, doi: 10.1109/TBME.2008.919734.

[9] S. Vijayakumar and S. Wu, "Sequential Support Vector Classifiers and Regression," Proceedings of International Conference on Soft Computing (SOCO '99), Vol. 
1999(619), pp. 610-619, 1999.

[10] M. Elistri, J. Wahyudi, and R. Supardi, "Penerapan Metode SAW Dalam Sistem Pendukung Keputusan Pemilihan Jurusan Pada Sekolah Menengah Atas Negeri 8 Seluma," J. Media Infotama Penerapan Metod. SAW...ISSN, Vol. 10(2), pp. 18582680, 2014.

[11] S. H. Sahir, R. Rosmawati, and K. Minan, "Simple Additive Weighting Method to Determining Employee Salary Increase Rate," Ijsrst, Vol. 3(8), pp. 42-48, 2017.

[12] E. Roszkowska and D. Kacprzak, "The fuzzy SAW and fuzzy TOPSIS procedures based on ordered fuzzy numbers," Inf. Sci. (Ny)., Vol. 369, pp. 564-584, 2016, doi: 10.1016/j.ins.2016.07.044.

[13] S. E. Widodo Sri, S. Lutfi, and Solikhin, "Sistem Pendukung Keputusan Penilaian Kinerja Karyawan Menggunakan Metode Simple Additive Weighting (SAW) Pada Pt. Indonesia Steel Tube Work," Sist. Inf., 2014.

[14] F. Fitriani, "Sistem Pendukung Keputusan Penentuan Jenis Rambut Manusia Dengan Menerapkan Metode Simple Additive Weighting (SAW)," Pelita Inform. Budi Darma, 2015.

[15] Ratnasari and T. Susilowati, "Sistem Pendukung Keputusan Kelayakan Pengajuan Kredit Sepeda Motor pada Dealer Tunas Dwipa Matra Gadingrejo Menggunakan Metode SAW," STMIK Pringsewu Lampung, pp. 442-448, 2016. 